Egyptian Poultry Science Journal

http://www.epsj.journals.ekb.eg/

ISSN: 1110-5623 (Print) - 2090-0570 (Online)

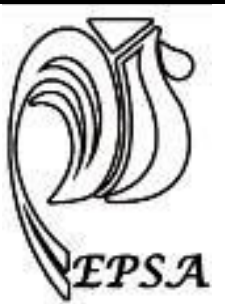

\title{
POTENTIAL RISK OF PSEUDOMONAS INFECTION IN BROILER CHICKENS WITH DETECTION OF THE ANTIBIOTIC RESISTANT GENES
}

Ghada, O. El-demerdash ${ }^{1}$, EL-shafei, A.A ${ }^{2}$, Amr, E. M. Mahmoud ${ }^{3}$ and Heba. Roshdy ${ }^{4}$

1-Anim.Health Res. Inst., Fayoum bran., Agric. Res. Center, Egypt

2- Anim. Health Res. Inst., Zagazig, Agric. Res. Center, Egypt

3-Bio. Dep., Fayoum Uni., Egypt.

4-Ref.e Lab. for Vet. Qual. Cont.on Poult. Prod., Anim. Health Res.Inst., Minis.of Agric., P.O. Box 246 - Dokki, 12618 - Giza, Egypt

Corresponding Author: E-mail: roshdy2019 @yahoo.com

Received: 17/08/2020 Accepted: $13 / 10 / 2020$

ABSTRACT:Pseudomonas aeruginosa is a bacterium causing high morbidity and mortality rates in chicken and other birds' particularly young age resulting in great economic losses. In this study a total of 100 samples of tracheal swabs, nasal swabs, liver, lung and heart (20 of each) were collected from birds at 7, 14, 21 and 35 days of ages from freshly dead and diseased broiler chickens broilers chicken Showing yellowish diarrhea, ruffled feather, respiratory manifestations, and conjunctivitis . Bacteriological examination for the prevalence of Pseudomonas aeroginousa isolation of (20) well identified strains of with $20 \%$ higher isolation from birds 7, 14 days than 21 and 35 Days old. The results of antimicrobial sensitivity of the isolates by vitek 2 system showed that the isolates were resistant to Tetracycline, Ampicillin, Amoxicillin/Clavulanic Acid, Chloramphenicol, Nitrofurantoin, and Trimethoprim while, they were sensitive to Amikacin, Cefpirome, Impenem, Piperacillin, Gentamicin and Tobramycin. The presence of the antibiotic resistance genes such as blaTEM (4/4) and mexR (4/4) for Pseudomonas aeruginosa were detected by Polymerase Chain Reaction in some $P$. aeruginosa isolates.

Key word: Pseudomonas aeruginosa- broiler chicken - vitek2 system- PCR- antibiotic sensitivity genes. 


\section{INTRODUCTION}

$P$ aeruginosa is an opportunistic organism produces septicemia and respiratory infections. It causesperihepatitis, pericarditis, congestion of internal organs, cheesy materials on the serous surfaces of, peritoneum. And airsacs in chickens Riad, (1994) and Abd El- Tawab et al., (2014). Infection with (P. aeruginosa) Associated with environment is mainly correlated with water, soil, and humid environments Finlayson and Brown, (2011) and Dinev et al., (2013). This bacterium is counted as one of the major bacteria causing severe problems in poultry farms. $P$ aeruginosa is Gram -negative, motile, nonspore forming rod present in short chain under microscope, grows on ordinary media, specialized with producing soluble green pigment and characterize with fruity odor Adams and Moss, (2008). $P$ aureginosa that causing infection and mortality rate of 50$100 \%$ especially in baby chicks. Saad et al., (2017). The Vitek2 system can detect dozens of specimens automatically at the same time. Therefore, Vitek2 system gave reliable, rapid and highly reproducible results Ling, et al., (2001). The virulence of $P$ aureginosa is due to cellular and extra cellular factors as elastase, lipopolysaccharide, pyocyanin, alkaline proteases, phospholipase C, haemolysins, pyoverdin, rhamnolipids, biofilm, flagella, and Pilli. Also, secrets toxins such as: exoenzyme $\mathrm{S}$, exoenzyme $\mathrm{T}$, exoenzyme $\mathrm{Y}$, and exoenzyme $U$ into the infected host. As these exotoxins excreted from pseudomonas which causes continuous infection even after the organism has been killed by antibiotics Kebede, (2010) and, Kirienko et al., (2015). There are many causes which increase the coincidence infection of Pseudomonas As stress conditions, infection with other diseases, viruses, mycoplasma and bacteria. All of these causes increase the chance of Pseudomonas infection which can occur at any age especially young age Stipkovits et al., (1993).
So, the aim of this work was identification of P. aeruginosa from broilers chicken samples. And identify its antibiotic susceptibility of the isolates using Vitek2 compact system. Besides, and resistance genes of the $P$. aeruginosa isolates.

\section{MATERIAL AND METHODS}

\section{Sample collection:}

A total of 100 samples of tracheal swabs, nasal swabs, liver, lung and heart (20 of each) were aseptically collected from freshly dead and diseased living broiler chickens at 7,14,21 and 35 days of age showing yellowish diarrhea, ruffled feather, respiratory manifestations, and conjunctivitis. Then, these samples were transferred in an ice box to laboratory for isolation and identification of Pseudomonas aeruginosa, According to Middleton et al., (2005).

\section{Isolation and identification:}

Collected samples were inoculated in nutrient broth tubes and incubated aerobically at $37^{\circ} \mathrm{C}$ for 24 hours, A loopfull was taken from this inoculated broth and stricked on MacConkey agar and Pseudomonas agar medium plates and incubated aerobically for $24-48$ hours at $37^{\circ} \mathrm{C}$; pigment production and lactose fermentation were detected respectively. The plates containing characteristic colonies of Pseudomonas aeruginosa (large, irregular, translucent and produced greenish diffusible pigment and characterized by its fruity smell) were selected and the Gram staining test was performed then subjected to biochemical identification according to Quinn et al., (2002). The method of isolates were also identified biochemically by vitek2 compact system according to Chatzigeorgiou et al., (2011).

\section{Sensitivity test of Pseudomonas aeruginosa} using Vitek2 compact system:

The antibiotic sensitivity test for identification of $P$. aeruginosa by Vitek 2 compact system and antimicrobial susceptibility test (AST-GN card) were done according to the manufactures' instructions Chatzigeorgiou et al., (2011). The microorganism suspension 
was transferred in to the identification ASTGN cards. This card identifies 47 different biochemically tests, and, the test tubes containing the microorganism suspensions were placed to special rack (cassette), then, this filled cassette placed into a vacuum chamber station where vacuum was done and reintroduced air. After the vacuum was applied and air was reintroduced into the station, the suspension of organism was transferred into micro-channels that fill all the test wells. Pseudomonas aeruginosa antibiotic sensitivity test was done against Amikacin, Tetracycline, Oxacillin, Ceftriaxone, Cefotaxime, Cefoperazone, Ceftazidime, Ciprofloxacin, Gentamicin, Impenem, and Piperacillin.

Detection of blaTEM and mexR genes in some Pseudomonas aeroginousa isolates using PCR:

DNA extraction was done from the 4 isolates using QIAamp DNA Mini kit (Qiagen, Germany, $\mathrm{GmbH}$ ) and modifications according the manufacturers' recommendations. Briefly, $200 \mu \mathrm{l}$ of the sample suspension were added to $200 \mu \mathrm{l}$ of the lysis buffer and $10 \mu \mathrm{l}$ of the proteinase $\mathrm{K}$ and incubated at $56^{\circ} \mathrm{C}$ for $10 \mathrm{~min}$, then, $200 \mu \mathrm{l}$ of $100 \%$ ethyl alcohol were added to the lysate. After that the sample was washing and centrifuging, and $100 \mu \mathrm{l}$ of the elution buffer which provided by the kit were used to elute the nucleic acid.

\section{Amplification of PCR}

Primers used for PCR amplification for blaTEM genes. These primers were utilized for the PCR reaction and for the analysis using forward and reverse PCR primers for blaTEM antibiotic resistant gene which was done according to Colom et al., (2003). The mexR antibiotic resistant gene was done according to Sánchez et al., (2002). As concluded in Table (1). The primers were utilized in a $25 \mu \mathrm{l}$ reaction containing 12.5 $\mu$ l of PCR Master Mix (Takara, Japan), $1 \mu \mathrm{l}$ of each primer of $20 \mathrm{pmol}$ concentration, $4.5 \mu \mathrm{l}$ of nuclease-free water, and $6 \mu \mathrm{l}$ of DNA template. The reaction was performed in an Applied Biosystem Thermal
Cycler. Cycling conditions of the different primers during the PCR amplification as the manufacturer's recommendations as described in Table (2).

\section{PCR product analysis}

The products of PCR were separated by electrophoresis on $1.5 \%$ agarose gel (Applichem, Germany, GmbH) in 1x TBE buffer at room temperature using gradients of $5 \mathrm{~V} / \mathrm{cm}$. For gel analysis, $20 \mu \mathrm{l}$ of the products was loaded in each gel slot. A gelpilot 100bp and 100bp plus DNA Ladders (Qiagen, Germany, GmbH) was used to determine the fragment sizes. The gel was photographed by a gel documentation system (Alpha Innotech, Biometra).

\section{RESULTS AND DISCUSSION}

Pseudomonas infections of birds are of great importance because epidemics may spread rapidly through poultry flocks causing mortality in all ages Shukla and Mishra (2015). This bacterium is counted as one of the major bacteria causing severe problems in poultry farms.

The bacteriological examination results for the 100 samples showed 20 positive isolates as 20 $\%$ for Pseudomonas aeruginosa, as shown in Table (3) which appeared in a green-blue color colonies with odor like a sweet grape. These results are in line with that obtained by Haleem et al., (2011), Abdel-Tawab et al., (2016), and Bakheet et al., (2017).

Result in Table (4), shown P. aeruginosa was highly isolated from liver followed from tracheal swabs, lung nasal swabs and finally from heart the results reported by Abd ElTawab et al., (2014), who mentioned that high prevalence with liver and negative with heart samples.

Table (5), reveals that Pseudomonas aeruginosa was in higher rate (10 positive) isolates from chicks of 7 day baby chicks, (6 positive) isolates from chicks of 14 day, ( 3 positive) isolates from 21 day chicken age which agreed with Abd El- Tawab et al., (2014), who reported that Pseudomonas spp. higher in baby chicks in the age ranged from 1 day to 10 days than older ages. Also, Kebede, 
(2010) found that the main reason of high mortalities in baby chicks was due to the infection by $P$. aeruginosa during hatching time from invading shells of egg or from the environment.

Table (6). The results Vitek2 system identification which proved by many laboratories worldwide who adopted the Vitek2 automated system for the identification of gram negative strains in ordinary clinical microbiology is rapid. Vitek2 system has many advantages. There is one negative control well and 47 biochemical that give final results in approximately 10 hours or less bioMérieux. (2006) and Chatzigeorgiou et al., (2011). First, it can avoid environmental contamination or cross-contamination as it is a closed system. Second, Vitek2 system can detect specimen card if it is misplaced on its cartridge. So, during its operation it owns a dependable recheck system. Third, it is easy for to prepare and load bacterial specimens by laboratory staff and the Vitek2 system can detect dozens of specimens automatically at the same time. So, Vitek2 system gives reliable, rapid and highly reproducible results Ling et al., (2001).

Table (7). The results of antibiotic sensitivity test proved that $\mathrm{P}$. aeruginosa strains were resistant to Tetracycline, Ampicillin, Amoxicillin/Clavulanic Acid, Chloramphenicol, Nitrofurantoin, Trimethoprim, Cefpodoxime and Ceftiofur. While they were sensitive to Amikacin, Cefpirome, Impenem ,Piperacillin Gentamicin,
Marbofloxacin and Tobramycin, which the reported with Kurkure et al., (2001), and Abdel-Tawab et al. (2016) proved high sensitivity with Ciprofloxacin and Gentamycin.

Detection of the antibiotic resistant gene of the tested Pseudomonas aeruginosa isolates by PCR showed that selected ones were positive for blaTEM gene giving amplicon at (516 bp )as shown in Fig (1). These results are in line with results obtained by Mombini et al.,( 2019), and Giriyapur et al.,( 2011) who found that almost of the Pseudomonas aeruginosa isolates were positives for blaTEM gene because the miss use of antimicrobial therapy as broad spectrum betalactams lead to mutations of genes for beta-lactams specially blaTEM .

Also, all the tested Pseudomonas aeruginosa isolates showed to be positive for antibiotic resistant mexR gene as shown in Fig (2). These results are in agreement with the results obtained by Walid et al., (2020). The most critical point is that bacteria could acquire virulence factors from the surrounding environment resulting in more alteration and causing cellular damages. Moss et al., (2019).

\section{CONCLUSION AND RECOMMENDATIONS}

P. aureginosa this bacteria causing severe problems in poultry farms. So, for minimize the economic losses in the poultry production firm hygienic measures should be applied. A strict antibiotic policy and establishment of infection control programs will help to lower the incidence of resistance in $P$. aureginosa. 
Table (1): Primers sequences, target genes and amplicons sizes.

\begin{tabular}{|c|c|c|c|}
\hline $\begin{array}{l}\text { Target } \\
\text { gene }\end{array}$ & $\begin{array}{l}\text { Primers sequences } \\
\text { Forward }\left(5^{\prime}-3^{\prime}\right) \\
\text { Reverse }\left(3^{`}-5^{\prime}\right)\end{array}$ & $\begin{array}{l}\text { Amplified } \\
\text { segment (bp) }\end{array}$ & Reference \\
\hline \multirow[t]{2}{*}{ blaTEM } & ATCAGCAATAAACCAGC & \multirow[t]{2}{*}{516} & \multirow{2}{*}{ Colom et al., 2003} \\
\hline & CCCCGAAGAACGTTTTC & & \\
\hline \multirow[t]{2}{*}{$\operatorname{mexR}$} & GCGCCATGGCCCATATTCAG & \multirow[t]{2}{*}{637} & \multirow[t]{2}{*}{ Sánchez et al., 2002} \\
\hline & GGCATTCGCCAGTAAGCGG & & \\
\hline
\end{tabular}

Table (2): Cycling conditions for each primer during PCR.

\begin{tabular}{|l|l|l|l|l|l|l|}
\hline $\begin{array}{l}\text { Target } \\
\text { Gene }\end{array}$ & $\begin{array}{l}\text { Primary } \\
\text { Denaturation }\end{array}$ & $\begin{array}{l}\text { Secondary } \\
\text { Denaturation }\end{array}$ & Annealing & Extension & $\begin{array}{l}\text { No. of } \\
\text { cycles }\end{array}$ & $\begin{array}{l}\text { Final } \\
\text { extension }\end{array}$ \\
\hline blaTEM & $94^{\circ} \mathrm{C}$ & $94^{\circ} \mathrm{C}$ & $54^{\circ} \mathrm{C}$ & $72^{\circ} \mathrm{C}$ & 35 & $72^{\circ} \mathrm{C}$ \\
& $5 \mathrm{~min}$ & $30 \mathrm{sec}$ & $40 \mathrm{sec}$. & $45 \mathrm{sec}$. & & $10 \mathrm{~min}$. \\
$\operatorname{mexR}$ & $94^{\circ} \mathrm{C}$ & $94^{\circ} \mathrm{C}$ & $55^{\circ} \mathrm{C}$ & $72^{\circ} \mathrm{C}$ & 35 & $72^{\circ} \mathrm{C}$ \\
& $5 \mathrm{~min}$ & $30 \mathrm{sec}$ & $30 \mathrm{sec}$. & $30 \mathrm{sec}$ & & $7 \mathrm{~min}$ \\
\hline
\end{tabular}

Table (3): Prevalence of P. aeruginosa in the examined samples.

\begin{tabular}{|l|l|l|l|l|l|}
\hline $\begin{array}{l}\text { No. of examined } \\
\text { samples }\end{array}$ & $\begin{array}{l}\text { No. of +ve } \\
\text { samples }\end{array}$ & $\begin{array}{l}\text { \%. of +ve } \\
\text { samples }\end{array}$ & $\begin{array}{l}\text { No. of -ve } \\
\text { samples }\end{array}$ & $\begin{array}{l}\text { \%.of -ve } \\
\text { samples }\end{array}$ \\
\hline 100 & 20 & $20 \%$ & 80 & $80 \%$ \\
\hline
\end{tabular}

+ ve (Positive samples), -ve (Negative samples)

Table (4): Distribution of Pseudomonas aeruginosa isolates in examined samples.

\begin{tabular}{|l|c|c|c|c|}
\hline Source of sample & $\begin{array}{c}\text { No. } \\
\text { of +Ve } \\
\text { samples }\end{array}$ & $\begin{array}{c}\text { \% } \\
\text { of +Ve } \\
\text { samples }\end{array}$ & $\begin{array}{c}\text { No. } \\
\text { of -Ve } \\
\text { samples }\end{array}$ & $\begin{array}{c}\text { \% } \\
\text { of -Ve } \\
\text { samples }\end{array}$ \\
\hline tracheal swabs & 5 & 25 & 15 & 18.75 \\
Nasal swabs & 3 & 15 & 17 & 21.25 \\
Heart & 2 & 10 & 18 & 22.5 \\
Lung & 4 & 20 & 16 & 20 \\
Liver & 6 & 30 & 14 & 17.5 \\
Total & 20 & 100 & 80 & 100 \\
\hline
\end{tabular}

Percentage calculated according to the number of isolates. 
Ghada, O. El-demerdash ${ }^{1}$ et al.

Table (5): Distribution of Pseudomonas aeruginosa isolates in the examined samples according to broiler ages.

\begin{tabular}{|l|l|l|l|l|}
\hline $\begin{array}{c}\text { broiler age } \\
\text { (day) }\end{array}$ & $\begin{array}{c}\text { No. } \\
\text { of }+ \text { Ve } \\
\text { samples }\end{array}$ & \multicolumn{1}{|c|}{$\begin{array}{c}\text { \% of +Ve } \\
\text { samples }\end{array}$} & $\begin{array}{c}\text { No. } \\
\text { of }- \text { Ve } \\
\text { samples }\end{array}$ & $\begin{array}{c}\text { \% of -Ve } \\
\text { samples }\end{array}$ \\
\hline 7 & 10 & 50 & 10 & 12.5 \\
14 & 6 & 30 & 14 & 17.5 \\
21 & 3 & 15 & 27 & 33.75 \\
35 & 1 & 5 & 29 & 36.25 \\
Total & 20 & 100 & 80 & 100 \\
\hline
\end{tabular}

Percentage calculated according to the number of isolates.

Table (6): biochemical of Pseudomonas aeruginosa using Vitek2 system.

\begin{tabular}{|l|l|l|l|l|l|l|l|l|l|l|l|l|l|l|l|l|l|l|}
\hline 2 & APPA & - & 3 & ADO & - & 4 & PyrA & - & 5 & IARL & - & 7 & dCEL & - & 9 & BGAL & - \\
\hline 10 & H2S & - & 11 & BNAG & - & 12 & AGLTP & - & 13 & dGLU & + & 14 & GGT & + & 15 & OFF & - \\
\hline 17 & BGLU & - & 18 & dMAL & - & 19 & dMAN & - & 20 & dMNE & - & 21 & BXYL & - & 22 & BAlap & + \\
\hline 23 & ProA & + & 26 & LIP & + & 27 & PLE & - & 29 & TyrA & + & 31 & URE & - & 32 & dSOR & - \\
\hline 33 & SAC & - & 34 & dTAG & - & 35 & dTER & - & 36 & CIT & + & 37 & MNT & + & 39 & 5 KG & - \\
\hline 40 & ILATK & + & 41 & AGLU & - & 42 & SUCT & + & 43 & NAGA & - & 44 & AGAL & - & 45 & PHOS & - \\
\hline 46 & GlyA & - & 47 & ODC & - & 48 & LDC & - & 53 & IHISa & - & & & & & & \\
\hline
\end{tabular}

APPA: Ala-Phe-pro arylamidase, ADO: Adonitol, PyrA: L-pyrrolydonyl-Arylamidase, IARL: L-Arabitol, dCEL: D-Cellobiose, BGAL: Beta-Glactosidase, H2S:H2S production, BNAG: Beta-N-Acetyl-Glucamindase, AGLTP: GlutamyleArylamidasepNA, dGLU: D-glucose, GGT: Gamma-Glutamyle-Transferase, OFF: Fermentation/ Glucose, BGLU: Beta-Glucosidase, dMAL: D-Maltose, dMAN: D-Mannitol, dMNE: D-Mannose, BXYL:Beta-Xylosidase, BAlap: Beta- Alanine Arylamidase Pna, ProA: L-Proline Arylamidase, LIP: Lipase, PLE: Palationose, TyrA: Tyrosine arylamidase, URE: Urease, dSOR: D-sorbitol, SAC: Saccharose/Sucrose, dTAG: Tagatose, dTER: DTerhalose, CIT: Citrate (sodium), MNT: Malonate, 5KG: 5-Keto-D-Gluconate, ILATK: L-Lactate alkanization, AGLU: Alpha-Glcosidase, SUCT:Succinate alkanization, NAGA: Beta-N-Acetyl, AGAL: Alpha-Glactosidase, PHOS: Phophatase, GlyA: Glycine Aryamidase, ODC: Ornithine Decarboxylase, LDC: Lysine decarboxylase, IHISa: L-Histidine assimilation.

+ ve (Positive ), -ve (Negative ). 
Table (7): antibiogram pattern of Pseudomonas aeruginosa isolates against different antibiotics.

\begin{tabular}{|l|c|c|c|c|c|}
\hline Antimicrobial & MIC & Interpretation & Antimicrobial & MIC & Interpretation \\
\hline Ampicillin & $>=32$ & $\mathrm{R}$ & Gentamicin & $<=1$ & $\mathrm{~S}$ \\
Amoxicillin/Clavulanic & $>=32$ & $\mathrm{R}$ & Tobramycin & $<=1$ & $\mathrm{~S}$ \\
Acid & & & & 2 & $\mathrm{I}$ \\
Pipracillin & 8 & $\mathrm{~S}$ & Enrofoxacin & $\mathrm{S}$ \\
Cifatexin & $>=64$ & $\mathrm{R}$ & Marbofloxacin & $<=0.5$ & $\mathrm{R}$ \\
Cefpodoxime & $>=8$ & $\mathrm{R}$ & Tetracycline & $\mathrm{R}$ \\
Ceftiofur & $>=8$ & $\mathrm{R}$ & Nitrofurantoin & $>=512$ & $\mathrm{R}$ \\
Cefpirome & 4 & $\mathrm{~S}$ & Chloramphenicol & $>=64$ & \\
Imipenem & 2 & $\mathrm{~S}$ & Polmyxin B & 2 & $\mathrm{R}$ \\
Amikacin & $<=2$ & $\mathrm{~S}$ & Trimethoprim/Sulfamethoxazole & 160 & \\
\hline
\end{tabular}

R: Resistance, I: Intermediate, S: Sensitivity. (MIC). Minimum inhibitory concentration.

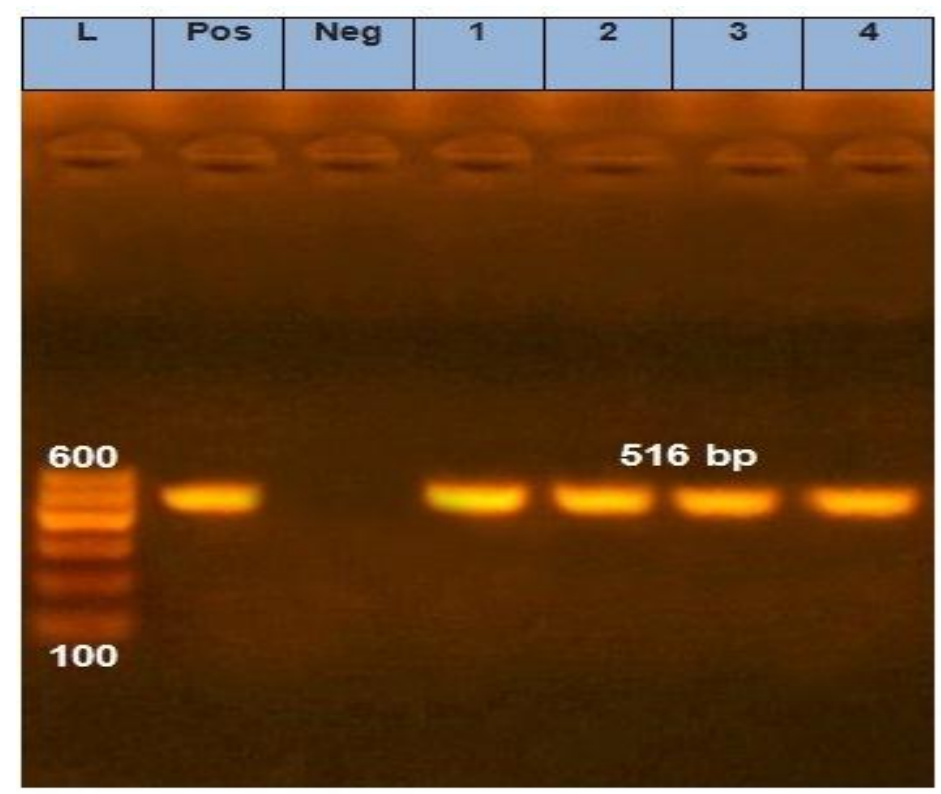

Figure (1) :Agarose gel electrophoresis of multiplex PCR amplification of Pseudomonas aeruginosa extracted DNA for blaTEM gene .L: represents the molecular size marker (DNA ladder-516bp). 1, 2, 3 and 4: are positive for blaTEM gene of Pseudomonas aeruginosa isolates. 


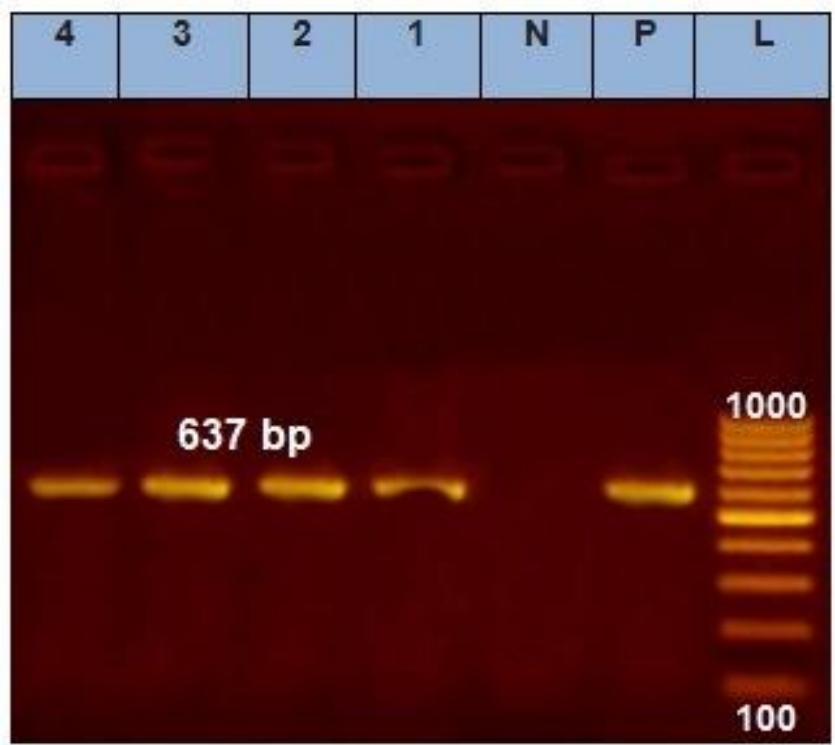

Figure (2) :Agarose gel electrophoresis of multiplex PCR amplification of Pseudomonas aeruginosa extracted DNA for mexR gene .L: represents the molecular size marker (DNA ladder637bp). 1, 2, 3 and 4: are positive for mexR gene of Pseudomonas aeruginosa isolates.

\section{REFERENCES}

Abd El- Tawab, A. A.; El-Hofy, F. I.; Khater, D. F. and Al-Adl, M. M., 2014: PCR detection and gene sequence of Pseudomonas aeruginosa isolated from broiler chickens. Benha Vet. Med. J., 27 (2): 449-455.

Abdel-Tawab, A. A.; Nasef, A. S.; Ibrahim, A. O., 2016: Bacteriological and molecular studies on bacteria causing omphalitis in chicks with regard to disinfectant resistance. Global Veterinaria, 17 (6): 539-545.

Adams, M. R. and Moss, M. O., 2008: Food Microbiology. $3^{\text {rd }}$ edition. The Royal Society of Chemistry, UK.

Bakheet, A. A.; Ali, M. N.; Sayed, H. A. and Nasef, A. S., 2017: Detection of Disinfectant resistant aerobic bacteria in unhatched chicken eggs. Benha Vet. Med. J., 32 (2): 248-259.
bioMérieux., 2006. Vitek 2 product information, document 510769-4EN1. Durham, NC.

Chatzigeorgiou, K. S.; Theodoros, N. S. and Pantelis, G. B., 2011: Phonex 100 versus Vitek2 in the identification of gram positive and gram negative bacteria. J. clin. Microbial, 49 (9): 3284-3291.

Colom, K., Pèrez, J.; Alonso, R.; FernándezAranguiz, A.; Lariňo, E. and Cisterna, R., 2003: Simple and reliable multiplex PCR assay for detection of blatem, blashv and blaoxA-1 genes in Enterobacteriaceae. FEMS Microbiology Letters 223: 147-151.

Dinev, I.; Denev, S. and Beev, G., 2013: Clinical and morphological studies on spontaneous cases of Pseudomonas aeruginosa infections in birds. Pakistan Vet. J., 33: 398-400.

Finlayson, E. A. and Brown, P. D., 2011: Comparison of antibiotic resistance and 
virulence factors in pigmented and nonpigmented Pseudomonas aeruginosa. West Indian. Med. J., 60: 24-32.

Giriyapur, R.S.; Nandihal, N. W.; Krishna, B.V.S.; Patil, A.B. and Chandrasekhar, M.R., 2011: Comparison of Disc Diffusion Methods for the Detection of ExtendedSpectrum Beta Lactamase-Producing Enterobacteriaceae. J. Lab. Physicians. 3(1): 33-36.

Haleem, H.; Kadhim, J.; Ilham, T. and Banyan, A., 2011: Isolation of Pseudomonas aeruginosa from clinical cases and environmental samples, and analysis of its antibiotic resistant spectrum at Hilla Teaching Hospital. Med. J. of Babylon, 8: 618-624.

Kebede, F., 2010: Pseudomonas infection in chickens. J. Vet. Med. Anim. Health., 2: 5558.

Kirienko, N. V.; Ausubel, F. M. and Ruvkun, G., 2015: Mitophagy confers resistance to siderophore-mediated killing by Pseudomonas aeruginosa. National Acad. Sci. USA., 112 (6): 1821-1826.

Kurkure, N. V.; Kalorey, D. R.; Shubhangiwarke, P. S. and Bhandarkar, A. G., 2001: Mortality in young broilers due to Pseudomonas aeruginosa. Indian J. Vet. Res., 10: 55-57.

Ling, T.K., Tam, P.C.; Liu, Z.K. and Cheng, A.F., 2001: Evaluation of Vitek 2 rapid identification and susceptibility testing system against gram-negative clinical isolates. J. Clin. Microbiol, 39 (8): 29642966.

Middleton, J.R.; Fales, W.H.; Luby, C.D.; Landsay Oaks, J.; Susan Sanchez, K. J.M. Wu, C.C.; Maddox, C.W. and Hartmann, F., 2005: Surveillance of Staph -ylococcusaureus in veterinary teaching hospitals. J. Clin. Microbiol. 43(6): 29162919.

Mombini, S.; S. E. Rezatofighi.; L. Kiyani, and H. Motamedi., 2019: Diversity and metallo- $\beta$-lactamase-producing genes in Pseudomonas aeruginosa strains isolated from filters of household water treatment systems. J. Environ. Manag, 231: 413-418.

Moss, D. L.; Park, H.; Mettu, R. R. and Landry, S. J., 2019: Deimmunizing substitutions in Pseudomonas exotoxin domain III perturb antigen processing without eliminating T-cell epitopes. J. Biol, Chem. 1-26.

Quinn, P. J.; Markey, B. K.; Carter, M.E.; Donnelly, W. J. and Leonard, F. C., 2002: Veterinary microbiology and microbial diseases. $1^{\text {st }}$ edition. Willy-Blackwell publisher, IN, USA.

Riad, E. M., 1994: Characterization of pseudomonas species isolated from domestic animals and poultry. Ph. D. Thesis (Microbiology), Fac. Vet. Med. Cairo Univ. Saad, Z. A.; Nasef, A. S.; Elhariri, M. and Elhelw, R., 2017: Resistance patterns associated with bacterial pathogens causing omphalitis in baby chicks. J. Biosci. Res., 14 (4): 845-851.

Sánchez ,P.; Linares, J. F.; Ruiz-Diez, B.; Campanario, E.; Navas, A.; Baquero, F. and Martinez, J. L., 2002: Fitness of in vitro selected Pseudomonas aeruginosa multidrug resistant mutants. J. Antimicrob. Chemother. Nov; 50(5):657-64

Shukla. And Mishra, P., 2015: Pseudomonas aeruginosa Infection in Broiler Chicks in Jabalpur. International J Ext Res., 6:37-39.

Stipkovits, L.; Glavits, R.; Vanics, E. and Szabo, E., 1993: Additional data on Mycoplasma disease of goslings. Avian Pathol, 22:171-176.

Walid, H. H., Ahmed, M. K. I. Salama, A, S, S and Hala, S. H. S., 2020: Virulence and resistance determinants in Pseudomonas aeruginosa isolated from pericarditis in diseased broiler chickens in Egypt. J .Adv. Vet. Anim. Res. Sep; 7(3): 452-463. 


\section{الملخص العربي}

\section{المخاطر المحتملة لعدوي السيدومونس في دجاج التسمين مع الكثف على جينات المقاومة

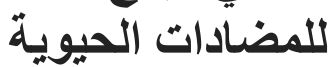

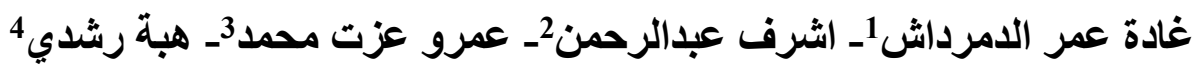

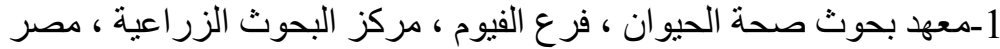

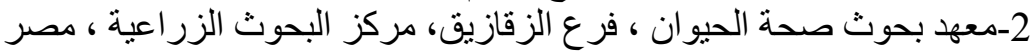

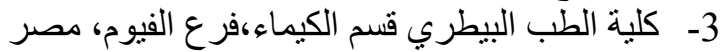

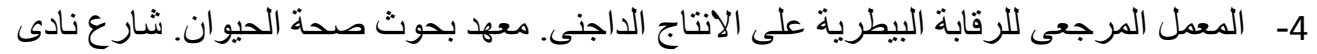

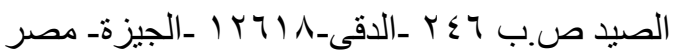

يسبب ميكروب السيدومونس ارجينوزا نسبه عاليه من الامر اض و النفوق في الطبور وخاصه الاعمار الصغيره. نم في هذا

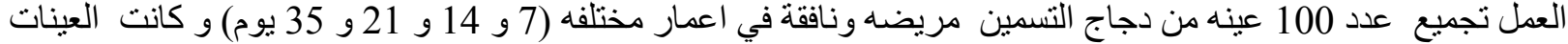

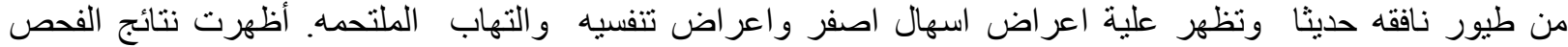

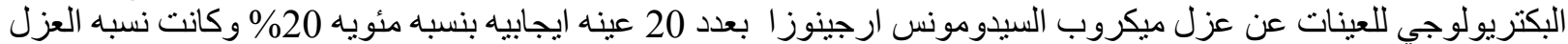

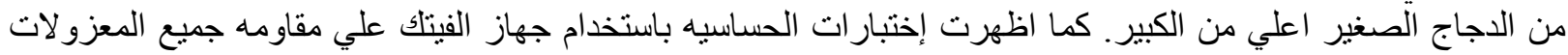

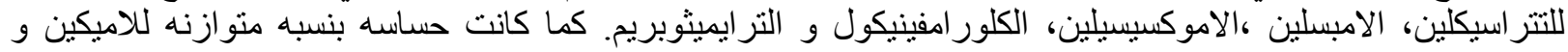

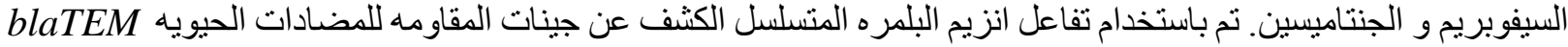
mexR. $4 / 4,4 \backslash 4$ 